\title{
The Role of Community Characteristics in determining Target Audiences in Arabic Gulf Countries interested in Online Purchasing through Commercial Smartphone Applications
}

\author{
Adel A. Bahaddad \\ Faculty of Computing and IT \\ King Abdulaziz University \\ Jeddah, Kingdom of Saudi Arabia
}

\begin{abstract}
Community's characteristics are important indicators in the study of disseminating electronic systems on a large scale. A community might be influenced positively to accept electronic systems if their basic requirements to use said electronic systems are commonly available. Therefore, determining communities' characteristics is the first pillar in identifying a population segment interested in online purchasing, followed by determining their requirements to interact with electronic systems successfully.
\end{abstract}

This study sought to identify common properties within the target audience for commercial smartphone applications in the Gulf Cooperation Council (GCC). Many academic studies point to the increasing volume of online trade exchange in GCC, as well as the rise in smartphone users, as compared with the overall population of the GCC. Thus, the success of m-commerce applications depends on two main aspects: identifying the target sector interested in online purchasing in the GCC region and identifying the technical requirements of the users in the target sector, so that $\mathrm{m}$-commerce applications can be created and adopted successfully in the GCC region. This study will benefit companies that want to activate electronic sales channels, such as commercial applications, over the Internet. These companies require accurate information about their audiences to help them succeed in activating these commercial applications. This data can be used to expand the target population in the future through many attractive promotions, such as loyalty programs.

The study method was quantitative (questionnaire), using samples from three GCC countries and incorporating four demographic moderators to determine audience characteristics: age, gender, user's previous experience, and educational level. The samples from Saudi Arabia (KSA), Qatar, the United Arab Emirates (UAE), and the overall total of completed responses were 386,171 , and 246 , respectively. These results were collected from participants who had previous experience in completing online transactions through commercial applications. Additionally, all participants had lived in the GCC for more than two years.

This study used the Information Systems Success (ISS) model, which has been tested on many electronic systems, but there exists a lack in studies regarding m-commerce approaches. Adding the demographic moderators into the ISS model determined the importance of each moderator to the ISS model and the study samples. The samples' characteristics were identified based on the demographic moderators and the success of commercial smartphone applications.

\section{Keywords}

Questionnaire Survey, GCC, M-Commerce, Commercial Application

\section{INTRODUCTION}

Commercial applications on smartphones represent one of the most important contributors to the success of the spread of ecommerce in this decade. They have sparked interest in many basic requirements for consumers in relation to technical requirements, including functions and information provided to assist the end user to make the right decision [1]. In addition, the requirements include consumer behaviours that can help to evaluate customer satisfaction and intention to use the mcommerce approach in future. The consumer behaviour requirements are built on the benefits for using the $\mathrm{m}$ commerce approaches regularly [2].

Increasing the level of online purchasing through electronic channels entails providing particular requirements for the target audience. The requirements of each community have a significant influence on their consumers in everyday life, and commercial considerations are part of this; moreover, ecommerce represents an integral part of this complex system [3]. Therefore, understanding the target population's characteristics represents one of the most important elements in determining who the main target consumers are and identifying their main requirements and products that they will prefer to purchase.

This study focusses on identifying the target segment characteristics across the commercial application by applying the ISS model to m-commerce. The model is modified by adding demographic moderators to understand and identify the characteristics [4]. Furthermore, the study is conducted on three samples from Gulf Cooperation Council (GCC) communities, which are interested in the spread of $\mathrm{m}$ commerce for many reasons. These include the level of per capita income for individuals, the spread of smart devices in these communities and the communities' significant spending on shopping compared to the other Arabic communities in the same region [5]. These factors represent the elements of the successful spread of commercial applications for smartphones. Therefore, defining the characteristics of the segment willing to purchase through commercial applications and determining their basic needs will help greatly when it comes to spreading online purchasing widely in Arab societies. 
This study focusses on samples from Arab societies, as few studies have been conducted in this area. Moreover, the studies that have been implemented in the traditional commercial field have not focussed on the same issue in ecommerce and $\mathrm{m}$-commerce, and they have therefore failed to take into account the significant difference between the target audiences in the traditional and electronic commercial fields.

This study presents the ISS model with proposed demographic moderators to determine the characteristics of the target audience for the commercial applications. Furthermore, it identifies the study methodology, associated analyses and hypotheses and discusses the study results', including the relationships and the connected effects between the ISS constructs.

\section{LITERATURE REVIEW}

This part of the article discusses and describes the literature review related to theoretical framework, which is based upon the research methodology of ISS. The ISS Model is one of the most prominent in the Information Systems (IS) field for measuring electronic framework performance and defining the basic criteria that will be helpful in achieving this task [6]. In this study, the most important research questions is determining consumers' characteristics who are dealing with commercial smartphone application that is influenced by Arabic traditions and purchasing via this method. The following sections are provided some significant information about the ISS model such as ISS model definition, the aspects that are tested through this framework, and the proposed amendments to the framework based on Arabic traditions. Also, it identifies indicators that are evaluated and measured by the ISS model. Because the ISS model would be an appropriate framework to predict relative success, it is used to add more moderators to identify the target audience of

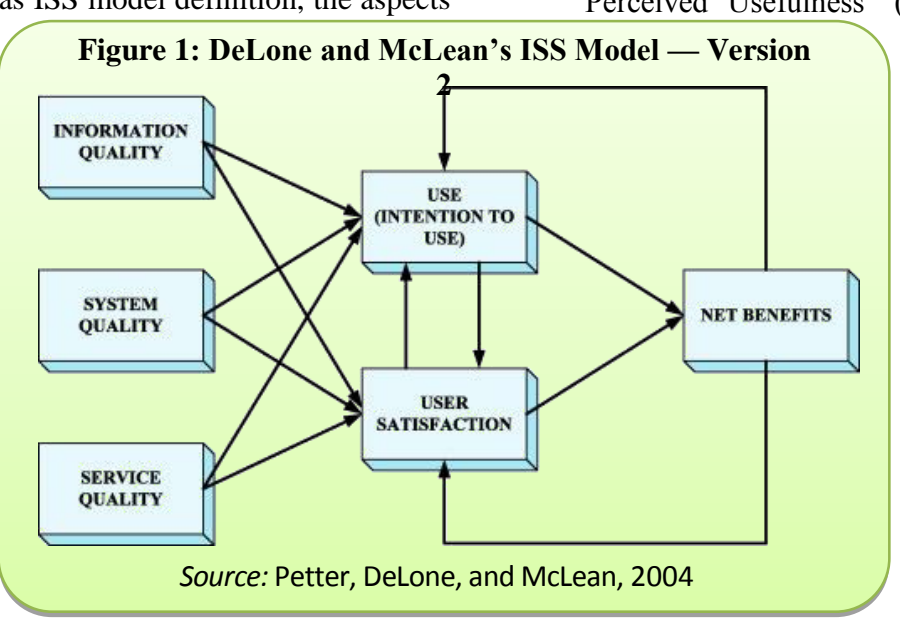
commercial smartphone applications to test them and create a more accurate and appropriate ISS model for used in the GCC.

\subsection{DeLone \& McLean - 2003 IS Success Model characteristics}

Information Systems, when used correctly, can help organizations to create efficient and effective communication, data access, and automation to assist business processes. As well as this, they can help researchers attain a high level of success and effectiveness in their social research process. However, a significant question remains regarding what the best way is to build a better measurement of ISS [2]. The DeLone \& McLean models are among the most comprehensive models for reviewing various measurements related to ISS. The DeLone \& McLean models contain proposed key elements to measure the level of success. These models are also considered close to ideal for measuring the complex variables in IS research ([6], [7], [8]). These elements, which are the main elements in the DeLone \& McLean models, do not provide a validation model for the experimental aspects of electronic systems. Many studies have also indicated that extra validity tests for information system are important, as are redefining the basic dimensions of what constitutes the success of the model. Furthermore, it is important to test the model in various experimental aspects to ensure its suitability in various electronic systems, specifically with respect to certain applications such as online purchasing ([6], [9], [10], [11])

Previous research related to ISS models for use in Mcommerce has centred on model validation, challenges facing model adoption, suggestions that could improve the original model, and thereby improve the model's acceptance level. The DeLone \& McLean updated model, which was designed in 2003 , was suggested the successful of e-commerce systems development that lead to the start of research into measurements of the success of e-commerce systems. Thus, some of literature review concerns have turned to developing and testing measurements of success in e-commerce systems [9], [12], [13]), and they confirmed that e-commerce processes fit well with the DeLone \& McLean Model - 2003. The ISS model which consists of six dimensions to measure success, and those researchers encouraged further testing of the model to determine the challenges the model faces and the main means by which the model can be optimally developed. The success of the existing ISS models in relation to ecommerce systems is a topic of some controversy with respect to some basic structural dimensions, such as 'IS Use' and 'Perceived Usefulness' ([7],[11],[14],[15]). Many previous studies have confirmed the way in which D \& M - 2003 works with the e-commerce process and have encouraged others to continue model testing and validation to identify challenges and suggest improvements in the original model that would facilitate acceptance of the model with new generations of online shopping systems ([6],[11],[14],[15], [16]).

The main purpose of this article is presenting a re-examination of the determinants of the ISS models' and verify the model to adopt the application of M-commerce systems in smartphones, depending on the success indicators in electronic marketing systems ([11], [14], [16], [17], [18], [19]). Therefore, this part focuses on the two main points. Firstly, a present the main finding of previous research that were conducted and developed the ISS models and engage with the preliminary discussions related to DeLone \& McLean during of 2003 and previous versions models. Secondly, a proposed variant to the ISS model is suggested for M-commerce systems for smartphones; the main assumptions of such a model are also set which present its result and hypothesis in the analysis and discussion parts.

\subsection{The updated DeLone \& McLean (2003) model Definition and Overview}

In 2003, DeLone \& McLean (see Figure 1) provided a new update of their ISS model. This update provided some adaptability for the subsequent changes in information systems practices, especially the emergence of the explosive growth of e-commerce via smartphones ([6], [20],[21]). The updated model was consistent with the Seddon hypothesis that the possibility of success in one model. These hypotheses are 
studied with previous models for ISS and suggestions that contributed to design the initial model that can be accepted [11]. This hypothesis can be confusing because it combines measures of success with partial evaluations of behaviour for IS model use. However, the reformulation represents both of these elements from the original Seddon - 1997 and DeLone \& McLean - 1992 models. This process makes the model more complex but eliminates the deficiencies embedded in previous models ([11],[15],[18]).

Based on the previous studies of the updated DeLone \& McLean - 2003 model, it was suggested that a Service Quality construct be added as a new dimension of the ISS model ([2],[15]). Furthermore, all influential elements related to individual and organisational impact are gathered under one dimension of measurement; namely, Net Benefit [15]. These dimensions represent dependent variables in a number of empirical studies ([6],[14],[22]). Additionally, a new dimension is presented, Intention to Use, as an alternative construct for IS Use. Intention to Use takes its importance from its role in the successful diffusion of e-commerce ([6],[8],[14],[15]). The Intention to Use dimension is key to spurring voluntary use of the IS system, which was previously one of the measurements of the ISS model and still is one of the most important measures in the updated DeLone \& McLean model ([15],[23]).

The updated DeLone \& McLean model confirms that the successful IS is multi-dimensional and interlinked, leading to the necessity of studying the interrelationship between these dimensions. The DeLone \& McLean - 2003 model indicates that work on the e-commerce framework between consumers and suppliers, as well as use of the electronic systems to assist buying or selling decisions or implement electronic commerce transactions, helps consumers make decisions to buy or sell using e-commerce, or implement such transactions ([6],[7],[15]). This helps make the way for a re-update of the DeLone \& McLean - 2003 model for use with online and ecommunications across smartphones, reflecting the new world of online trading measurement and especially online purchasing across smartphones and commercial applications.

DeLone and McLean's new model, updated in 2003, is divided into six dimensions; each concept is consistent with one or more of the other dimensions [6]. The dimension aspects can be defined as follows:

- System Quality (SQ) determines the characteristics that should be included as basic requirements in the system, for example: ease of use, system flexibility, system reliability, and learnability ([6],[23]).

- Information Quality (IQ) focuses on the basic output characteristics of the system, which include management reports and information displayed on the screen or web pages; for example, information that should be known because of its importance, completeness, understandability, brevity, accuracy, and timeliness ([6],[23]).

- Service Quality (SQU) involves the features and support that should be provided by the IT technical support team for the system users, for example, reliability responsiveness, accuracy, and technical competence. Service quality has been adapted from the field of marketing. As one of the popular measuring tools [28], it has been added to the second version of the ISS Model ([6],[23]).

- Intention to Use (IU) refers to the degree of using system regularly in the future and methods that should be employed by staff and customers to take advantage of IS capabilities; for example, nature of use, frequency of use, convenience, amount of use, and purpose of use [15].

- User Satisfaction (US) concerns the level of satisfaction with the information provided in the system, and features information via reports, websites, and support services such as the tools that can be used to measure user satisfaction [24].

- Net Benefits (NB) contribute to individual, group, and organisational success, for example, improving the decision-making process, reducing costs, fostering market efficiency, increasing sales, improving productivity, and boosting profits ([15]).

Practical adoption of DeLone and McLean's model depends on the organisational context. Therefore, the process and context of the information system in any study must be understood to determine the types of measures that should be used for each dimension of success [23]. Choosing the dimensions of success includes specific measurements based on the nature and purpose of the system that will be evaluated. For example, applying M-commerce in this study requires examining particular measurements and indicators to achieve success in this field, which is different from other working environments ([6],[22]).

\subsection{ISS study in the M-commerce field}

Based on material presented in the previous sections, this study proposes a multi-dimensional system that represents a successful M-commerce model which uses the DeLone and McLean - 2003 model initially (see Figure 1). Information Quality, Quality Systems, Service Quality, User Satisfaction, Intention to Use, and Net Benefit of the electronic systems are the main constructs used for the model.

It was mentioned by Molla and Licker (2001) that a model for e-commerce success could be proposed on the basis of the DeLone and McLean - 2003 and Seddon - 1997 models. These researchers proposed a model based on six dimensions, which are: e-commerce system quality, content quality, use, trust, support and services, and customer e-commerce satisfaction ([6], [9]). In particular, the model focuses on the conceptual elements, and User Satisfaction, Intention to Use, and Net Benefits, these constructs have been used in this study without any change. However, other constructs, which are, System Quality, information Quality, and Service Quality have been changed in the current search in accordance with the facts of previous research that supports the adjustment process, which helps in building the right model in mobile commerce ([6],[9],[15], [25])

There is another model that appeared before the DeLone \& McLean - 2003 model which was developed by Pitt and colleagues (1995) (see Figure 2). This model was suggested between DeLone \& McLean - 1992 and Seddon - 1997. The model suggestion is Service Quality, which is similar to the DeLone \& McLean - 2003 model, and is important for the adoption of electronic system applications. As mentioned previously, the importance of after-sales services to facilitate the acceptance of electronic applications represents one aspect of ISS in both the DeLone and McLean models ([13],[15],[23],[26]). A broad cross-spectrum of previous research has concentrated on the importance of service quality to the acceptance of e-commerce ([8],[15],[27],[28]). Moreover, another study by Wang and Tang (2003), presented an important approach for e-commerce service quality to build a multi-dimensional model, which includes reliability, responsiveness, empathy, and the building of loyalty to a company ([29],[30]). Furthermore, the capability of a company to transfer confidence to consumers through various 
means of electronic communication is vital in the success of M-commerce systems ([21],[31],[32]). Also, the trust concept is considered as part of Service Quality in an e-commerce approach ([9],[33]). Thus, the interoperability in the ISS models is possible, if trust is considered a part of Service Quality, rather than some other separate parameter ([9],[33],[34]). Starting at this point, the hypothesis of this study is able to be tested and identify the main characteristics of target audience based on suggested model moderators that connected between System Quality, Information Quality, and Service Quality from first side and User satisfactions and Intention to use from another side in M-commerce field.

\section{THE MODEL MODIFIED BY THE RESEARCH FRAMEWORK RESEARCH HYPOTHESIS}

The relationships between the constructs that are tested in this research can be divided into theoretical and experimental. The theoretical relationships, which are called the customer behaviours, contain the constructs User Satisfaction, Intention to Use, and Net Benefits. The experimental relationship constructs which are called the practical customer requirements, are separated into System Quality, Information Quality, and Service Quality. The hypothesis that focuses on the experimental relationship is related to commercial applications indicators that focus on the practical side in this research. Many previous marketing studies have indicated that Systems Quality, Information Quality, and Service Quality lead to user satisfaction and thus regular return shopping ([13],[24],[35],[36],[37],[38],[48]). This part of the study will focus on the following three hypotheses:

H1. The SQ constructs' indicators will have a positive effect on US with the use of smartphone M-commerce applications.

H2. The IQ constructs' indicators will have a positive effect on US with the use of smartphone M-commerce applications.

H3. The SQU constructs' indicators will have a positive effect on US with the use of smartphone M-commerce applications.

Figure 2: Pitt and other IS Success Model (1995)

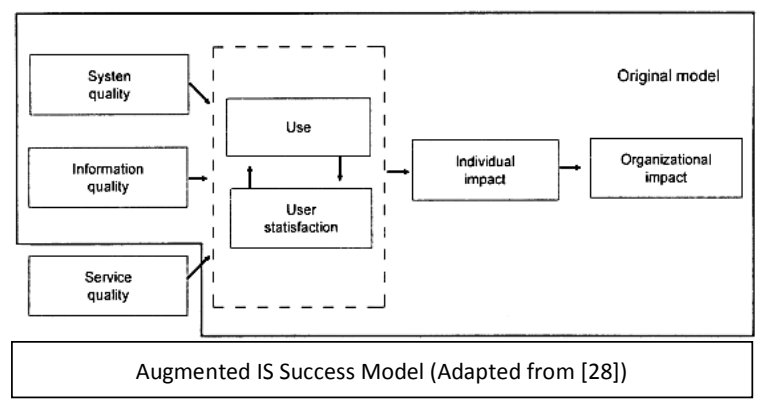

Many previous studies focused on Intention to Use, which results from quality systems that directly motivate consumers to purchase from the same M-commerce system multiple times ([27],[38],[39],[40]). In addition, other studies have suggested that Net Benefits also contribute to increased customer loyalty $([6],[8],[15],[27],[28])$. [41] noted that customers obtaining a low level of benefits from one shopping experience online will tend to switch to other competitive companies to increase their benefit (2003). This directly reduces customer loyalty and degrades the intention to use a site to purchase more goods ([41],[42]). Therefore, connecting the quality constructs and consumer behaviour is important and leads to consistent advances in the correlation between the value of consumer loyalty and the electronic systems in general, and M-commerce applications in particular ([16],[29],[39],[43],[44], [45],[46]). Also, Parasuraman and Grewal saw that quality, as seen from the perspective of loyalty, still requires further research. This part of the study focuses on the following hypotheses:

H4. The SQ constructs' indicators will have a positive effect on IU with the use of smartphone M-commerce applications.

H5. The IQ constructs' indicators will have a positive effect on IU with the use of smartphone M-commerce applications.

H6. The SQU constructs' indicators will have a positive effect on IU with the use of smartphone M-commerce applications.

US and IU are heavily influenced by constructs such as SQ, IQ, SQU, and Net Benefit obtained by the user from another site ([6],[15]). NB represents the building of a knowledge base which is an important aspect of what the user would be getting when dealing with new technologies, similar to companies' benefits from providing new technical methods for displaying products electronically. Thus, there is mutual benefit for these two parties; therefore, these parties experience mutual benefit ([11],[14],[15]). However, User Satisfaction and Intention to Use are assessments of emotional response ([37],[44]). Electronic systems in M-commerce indicate that the benefit for the seller comes after customer satisfaction, when his or her response is frequent online purchases in the future ([13],[41]). Research has also focused on Net Benefit as one result of User Satisfaction and Intention to Use ([13],[25],[39],[47],[48]). From this, the following hypotheses can be developed:

H7. US indicators will have a positive effect on NB with the use of M-commerce applications in smartphones.

H8. The IU indicators will have a positive effect on NB with the use of M-commerce applications in smartphones.

The DeLone \& McLean - 2003 model indicates that the positive use of electronic systems leads to greater user satisfaction. Similarly, increasing user satisfaction leads to increases in frequency of use and in intention to use ([17],[19],[38],[43]). With their purpose being to simplify the close relationship between User Satisfaction and Intention to Use and Net Benefit, H7, H8, and H9 suggest that increased user satisfaction is the reason Intention to Use occurs, leading to increased use, increased Net Benefit, and increased User Satisfaction. The importance of the proposed link between the three constructs with respect to overall consumer behaviour during use of MISs has been clarified ([13],[25],[28],[30],[48],[49]). Furthermore, the importance of User Satisfaction and Intention to Use arises from a marketing standpoint, in the fact that the marketing standpoint is an emotional, user-experience parameter whether to buy again in the future. Much depends, then, on the Intention to Use construct ([45],[50],[51],[52]). Behavioral variables such as intent to re-use and word-of-mouth recommendations are among the basic means by which consumers express satisfaction and confidence in electronic systems [2] Additionally, customers who are dissatisfied with current sales are more likely to comply with the policies of new competitors, even if they differ from their previous online commerce experiences. Satisfied customers, who have made previous online purchases, will express satisfactory behaviour. ([13],[41],[53]). These concepts led to the following hypothesis: 
H9. US indicators will have a positive effect on the IU with use of smartphone M-commerce applications.

Complementing the above, the hypotheses H1 to H6 are tested again under following four demographic moderators related to the GCC societies which are Gender, Age, previous experience, and level of education.

\section{METHODOLOGY}

The methodology of this study involves the use of a questionnaire as a suitable method to access the views of target participants. The lack of requirement studies related to commercial applications in the m-commerce field in the GCC led to measurement of the main requirements by asking the participants closed direct questions. It is appropriate to elicit the participants' opinions using a Likert scale because they lack experience when it comes to determining the minimum requirements they need to accept and use commercial applications via smartphones. Therefore, consumers' requirements were taken into account and the participants were asked about the importance of these indicators. The groups were classified six sub-groups, symbolised as SQ, IQ, SQU, IU, US and NB. There were 23 indicators, and an online survey was employed to gain easy access to a diverse group of participants ([54],[55]).

Several processes were implemented to ensure the survey's validity. Three conditional questions were employed to ensure that the participants belonged to the right sample. The questions were asked to ensure that the participants had previous experience in m-commerce, were residents of GCC and had completed online purchasing previously through any online purchasing channels. In addition, the survey explained the purpose of the questionnaire and provided the contact information for research team to answer any inquiries the participants had [56].

The total numbers of completed responses were 408, 175 and 252 from the Kingdom of Saudi Arabia (KSA), Qatar and United Arab Emirates (UAE), respectively. The sample size was calculated according to the target number, level of confidence $(95 \%)$ and margin of acceptable error $(7.5 \%)$. The survey was conducted during the period of January-August 2014.

\begin{tabular}{|c|c|c|c|c|c|c|c|}
\hline \multicolumn{8}{|c|}{$\begin{array}{l}\text { Table 1: Summary of Frequency, attitude, and Cronbach's Alphas of } \\
\text { Measurement Scales of all constructs depending on each country }\end{array}$} \\
\hline \multicolumn{2}{|c|}{ Construct code } & SQ & IQ & SQU & IU & US & NB \\
\hline \multicolumn{2}{|c|}{ No of Items } & 2 & 5 & 6 & 3 & 3 & 4 \\
\hline \multirow{4}{*}{ 氙 } & Mean & 4.611 & 4.69 & 4.45 & 4.033 & 4.643 & 4.086 \\
\hline & SD & 0.526 & 0.35 & 0.396 & 0.531 & 0.477 & 0.631 \\
\hline & Attitude & S.A. & S.A. & S.A. & A. & S.A. & A. \\
\hline & Realbility & 0.705 & 0.632 & 0.634 & 0.607 & 0.78 & 0.601 \\
\hline \multirow{4}{*}{ 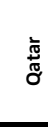 } & Mean & 4.094 & 4.467 & 4.49 & 4.07 & 4.675 & 4.14 \\
\hline & SD & 0.615 & 0.435 & 0.413 & 0.601 & 0.429 & 0.663 \\
\hline & Attitude & A. & S.A. & S.A. & A. & S.A. & A. \\
\hline & Realbility & 0.703 & 0.751 & 0.655 & 0.654 & 0.733 & 0.619 \\
\hline \multirow{4}{*}{ 岁 } & Mean & 4.465 & 4.5 & 4.543 & 4.228 & 4.599 & 4.098 \\
\hline & SD & 0.535 & 0.433 & 0.414 & 0.566 & 0.502 & 0.647 \\
\hline & Attitude & S.A. & S.A. & S.A. & S.A. & S.A. & A. \\
\hline & Realbility & 0.725 & 0.679 & 0.667 & 0.6 & 0.754 & 0.616 \\
\hline \multicolumn{2}{|c|}{ Cronbach's Alpha (ALL) } & 0.727 & 0.715 & 0.626 & 0.62 & 0.764 & 0.617 \\
\hline \multicolumn{2}{|c|}{ Validity (ALL) } & 0.87 & 0.846 & 0.791 & 0.787 & 0.874 & 0.785 \\
\hline
\end{tabular}

\section{ANALYSIS}

There are several statistical tests which are used to calculate the significant relationships between the constructs together and between the constructs and the moderators. It is contained the Mean, Standard Division, Cronbach's Alpha, and linear regression test. There are more details about the study results in the following parts.
Kline (2005) noted the importance of consistency in the participants' answers, which is known as Factor Internal Consistency or Cronbach's alpha coefficient. It is the most common measure of internal consistency [57]. The values for Cronbach's alpha coefficient range from 0 and 1. A lower Cronbach's alpha value indicates that the variables may be heterogeneous and their ability to represent the construction is weak; a higher value indicates that the variables are homogeneous and they have a strong ability to represent the construction. A Cronbach's alpha coefficient of 0.60 or above is acceptable as an indicator of internal consistency and it represents the minimum degree of internal consistency between the indicators in the constructs ([41],[58]). The information shown in Table 1 presents the internal consistency scale of the 6 constructs of indicators, which represents the 23 indicators proposed in the ISS model. The Cronbach's alpha coefficient values for the KSA sample was 0.660, UAE sample was 0.674 , and the Qatar sample was 0.686 . The Cronbach's alpha coefficient values of all the scales ranged between 0.601 and 0917 for each construct in each country, which indicates good internal consistency and reliability for this sample.

The constructs, which represent the fundamental aspects of the ISS Model are SQ, IQ, SQU, IN, US, NB. Their construct mean in the KSA sample was between 4.0328 and 4.6896. In Qatar, the sample mean was between 4.0702 and 4.6745 , while in UAE, the sample mean was between 4.0976 and 4.5989. In these constructs, the means indicate that their importance varies depending on the participants' differing opinions of the samples. This indicates the importance of obtaining more details for these constructs, which is covered later in the discussion chapter.

\subsection{The moderator's hypothesis}

Many of the previous studies were performed on various technical models, such as ISS, UTAUT and TAM, and in those models determinants are a fundamental requirement for accepting an information technology approach, and communities characteristics should be taken into consideration when accepting and activating new technologies ([13],[59],[60]). A variety of previous studies found that the demographic questions can be as moderating in the theoretical model. These moderators have been adopted in many of the previous research models, such as UTAUT, TAM and ISS, and they have also shown good acceptance values in the research field. In this current research study, there are four parameters that can be verified as moderators: Age, Gender, Experience and Education level. These represent the characteristics related to the acceptance and understanding of new forms of technology based on the characteristics of the different societies studied. Therefore, according to the study conducted by Sun and Zhang (2006), it is necessary to identify the potential effects that these demographic moderators have on a user's technology acceptance. Thus, in this part of the analysis, the four moderators are tested to determine the significant paths they take in the model. Each of the four demographic moderators was divided into two groups with fixed values, as follows:

1. Gender, which was divided into male and female groups.

2. Age, which was divided into one group of people who were 35 or older, and a second group of people who were younger than 35 .

3. Experience, which is called frequency in the analysis table, referred to the number of purchases made via mobile commercial application. This group was divided into a high level group that made more than one purchase a month and a low level group that made less than one 
purchase a month via a mobile device.

4. The level of education, which was divided into a postgraduate group of people with a master's degree or higher, and an undergraduate group of people with a bachelor's degree or no college education.

The number of participants in each group and their participation percentages are presented in Table 2.

The main purpose of the moderator groups is to explore the differences between the participants in the study samples and to determine the acceptance of the ISS model path in commercial mobile applications in smartphones. These values were calculated to determine the significant path correlation coefficients, critical ratios and $\mathrm{P}$-values for each of the links between the model's constructs that are associated with the demographic hypotheses, in order to determine the significant relationships between the constructs in the ISS model.

\begin{tabular}{|c|c|c|c|c|c|c|}
\hline \multirow{2}{*}{$\begin{array}{l}\text { Group } \\
\text { level }\end{array}$} & \multicolumn{2}{|c|}{ KSA } & \multicolumn{2}{|c|}{ Qatar } & \multicolumn{2}{|c|}{ UAE } \\
\hline & $\mathbf{N}$ & $\mathbf{p}$ & $\mathbf{N}$ & $\mathbf{p}$ & $\mathrm{N}$ & $\mathbf{P}$ \\
\hline \multicolumn{7}{|c|}{ Gender } \\
\hline Male & 225 & $58.3 \%$ & 101 & $59.1 \%$ & 135 & $54.9 \%$ \\
\hline Female & 161 & $41.7 \%$ & 70 & $40.9 \%$ & 111 & $45.1 \%$ \\
\hline \multicolumn{7}{|l|}{ Age } \\
\hline Young & 250 & $64.8 \%$ & 111 & $64.9 \%$ & 132 & $53.7 \%$ \\
\hline Old & 136 & $35.2 \%$ & 60 & $35.1 \%$ & 114 & $46.3 \%$ \\
\hline \multicolumn{7}{|c|}{ Frequency } \\
\hline High & 193 & $50.0 \%$ & 91 & $53.2 \%$ & 133 & $54.1 \%$ \\
\hline Low & 193 & $50.0 \%$ & 80 & $46.8 \%$ & 113 & $45.9 \%$ \\
\hline \multicolumn{7}{|c|}{ Education } \\
\hline P. G. & 200 & $51.8 \%$ & \begin{tabular}{|l|}
88 \\
88
\end{tabular} & $51.5 \%$ & $\begin{array}{l}115 \\
\end{array}$ & $46.7 \%$ \\
\hline U.G. & 186 & $48.2 \%$ & 83 & $48.5 \%$ & 131 & $53.3 \%$ \\
\hline
\end{tabular}

\subsection{Overview of moderators results}

The differences in the Gender moderator results for each of the study samples show that the average of all of the male samples taken together is $57 \%$, while the average for all of the female samples is approximately $43 \%$. The results also show the paths between the influenced by Gender links moderators: SQ-IU, SQ-US, IQ-IU, IQ-US, SQU-IU and SQU-US. The correlation coefficient for all of the female groups in the study samples are significant, while no significant relationship between the same paths was found in the male groups in the study samples. This indicates that the female sector in the sample study is much more strongly interested in online shopping than the males due to the availability of many options over the Internet. This is considered to be one of the main factors that dramatically attract female mobile application users. Furthermore, significant relationships were found between SQ-US and IQUS in the male group in all of the sample studies. This shows the importance of user satisfaction if an M-commerce application is to be acceptable and meet the requirements associated with the constructs. The entire statistical relationships link values in the ISS Model associated with the Gender moderator are presented in Table 3.

The Age moderator results of the samples are slightly different from the gender differences. In all of the samples, the average percentage of the participants in the young group (people less than 35 ) is about $61 \%$, while the percentage of participants in the older group (greater than 35) is $39 \%$. All of these links have a significant correlation coefficient for the younger group (less than 35) for all of the study samples, which indicates that the number of young people who are interested in using online shopping is larger. A significant statistical relationship appeared between SQ-US and IQ-US in all of the study samples, and this shows that user satisfaction is significant for all of the model constructs.
Differences in the Frequency moderator results, which focus on the experience side as a motivation or intention to make mobile purchases in the future, were slightly different between the study samples. In all of the study samples, the percentage of participants who made a purchase using a mobile device more than once a month was around $52 \%$ and the percentage of participants who used a mobile device to make a purchase less than once a month was $48 \%$. In all of the study paths, SQ-IU, SQ-US, IQ-IU, IQ-US, SQU-IU and SQU-US were shown to have a significant relationship at the high frequency level only in the KSA and Qatar samples; however, the results do not show any significant relationship in UAE sample or in the other low frequency level groups. This reinforces the importance of experience level in accepting and using mobile commercial applications via smartphones in the future for some of GCC societies.

Figure 3: Choosing Target Audience Model

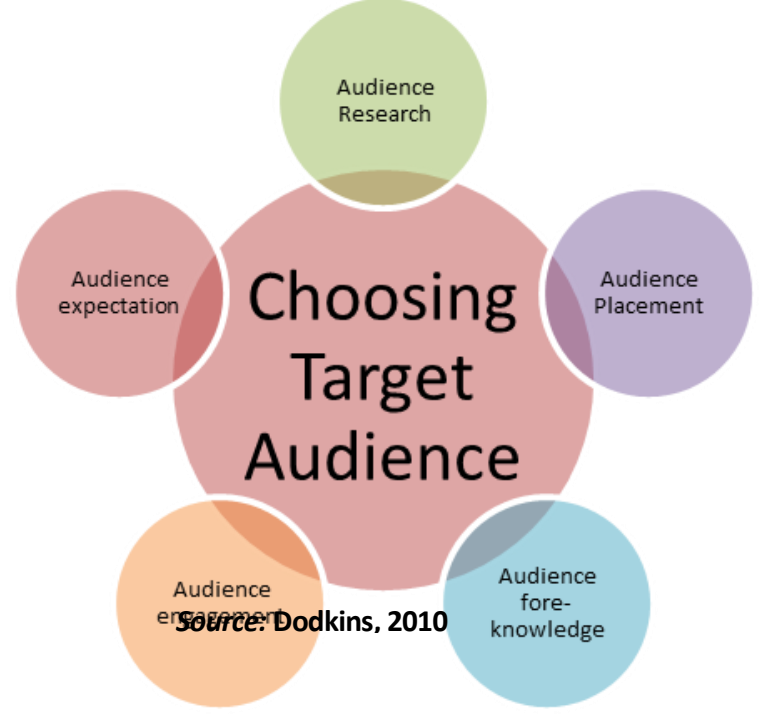

The study sample results show that the impact that the Education level moderator has on decision-making regarding making purchases via smartphones is significantly different from the Gender and Age moderator study sample results. The percentage of participants with a postgraduate education was $50 \%$ and the percentage of participants with a bachelor's degree or less was also $50 \%$. The study path results for SQ-IU, SQ-US, IQ-IU, IQ-US, SQU-IU and SQU-US showed a significant relationship between the postgraduate groups in KSA only, not similar the postgraduate groups in the Qatar and UAE study samples. This indicates that using a mobile commercial application via a smartphone is an important moderator for audience in KSA, the people who have postgraduate education represent $(1.4 \%)$ who has a postgraduate education [61]; because this population segment is high in numbers in the Saudi population and they have suitable skills for self-learning in order to use new technology. However, this moderator presented an insignificant relationship in Qatar $(0.9 \%)$ and $\operatorname{UAE}(0.7 \%)$ because the proportions of the educated class in both nations are lower than $1 \%$. Therefore this moderator does not represent a statistically significant difference in the Qatar and UAE study samples ([62],[63]).

\subsection{The Result of Model Moderators}

The moderator results have been previously presented. They included Gender, Age, Frequency, and Education (see Table $3)$. The results indicated the significant relationship at the group level and the path level in all of the moderators and all of 
the study samples. The Gender moderator results showed that the female group has a significant link in all of the influence constructs and in all study samples, unlike the male groups that did not show the same relationship results. The Age moderator showed significant results for the young group in all of the study samples, while the older group did not appear to have any fully significant relationships in any of the group constructs. The Frequency moderator results showed a significant relationship in both the KSA and Qatar samples, but not in the UAE sample. In contrast, the results did not appear to show fully significant relationships in the low frequency purchaser group in any of the constructs. Additionally, the Education moderator results appeared to be heterogeneous, which showed a significant result in the postgraduate group in the KSA sample only; while a fully significant relationship was not apparent in the other sample results or in the undergraduate groups. These results indicate a mixed, statistically significant difference between the study samples and the model moderators.

\section{DISCUSSION}

It is important to discuss relationships that appeared in the analysis to understand the basic characteristics of the target audience. These characteristics might be helpful in spreading the use of commercial applications for smartphones. The discussion highlights two main topics, namely the characteristics that define the target audience and the main characteristics of the target audience in GCC societies that will help to spread e-purchasing through commercial applications. Further details about these two main issues are presented in the following sections.

\subsection{General characteristics of the $M$ - commerce targeted segment influenced by demographic moderators}

One of the main characteristics of the target segment's functionalities is the need to determine both the potential impact of demographic moderators on the acceptance level of the target audience and the fundamental boundaries to attract a market segment in the future ([2],[64]). These moderators help to identify the characteristics of the target audience and determine any relationships between constructs in the model that need to be studied more deeply in the future ([2],[65]). This section of the study focuses on two particular properties: the characteristics of relationships within each demographic moderator and the significant relationships in special paths within the ISS model. These paths show a statistically significant relationship between IQ and US as well as between SQU and US. The relations also show statistically significant results for all demographic moderators as well as for all study samples.

\subsection{Determinants of smartphone application acceptance among the target audience}

One of the main questions that comes to mind when a new business project is started is: what are determinants that help the appropriate segment (the target audience) accept and adopt this project? In the current case, the question is concentrated on the characteristics of the target audience to use and accept M-commerce executed through smartphones. This does not mean that other segments are not interested in purchasing online using smartphone devices. One of the main 'pillars of success' for improving a core business is to find those who are interested, so the segment can (in this case) help to diffuse Mcommerce broadly through commercial applications in a short time through choosing a target audience model (see Figure 3), the basic parameters of which allow recognition of the properties of the target audience; that is, those who are interested in electronically purchasing items via commercial mobile applications. These dimensions can be summarised by focusing on parameters including audience expectation, engagement, foreknowledge, audience placement and audience research. They will be reviewed here.

(i) Audience expectation: Is it possible to predict what products or services might meet the audience's interest? Audience expectation focuses on the expected products and services that the customer desires from commercial smartphone applications. Customers have various product-related expectations; these might be built on the interesting diversity of online purchase groups that use smartphones ([66],[67]). To use women as an example of what this diversity means, in the GCC countries women are generally interested in things such as home decoration products, equipment, and devices that will help facilitate housework. Furthermore, women focus on purchasing jewellery and cosmetics as important personal products that can be purchased regularly, even by those in the middle class who have limited income. Another example of diversity comes into focus when one looks at those under the age of 35 years. This group focuses on clothing and personal effects, electronics that facilitate their work or life, and car accessories of various designs and purposes. Other moderators in this study focus on elements such as education level and past experience with M-commerce to determine segmentation and product expectations. Another aspect of expectations is the services expected; these have been presented and addressed in the main 'findings' chapter in this study.

(ii) Audience engagement: This refers to the appropriate means of communication with one's audience, and the means that can be used to attract the desired segment, especially in the fields related to M-commerce. Many are interested in using social communication applications to deliver ideas in innovative ways [68]. Some social media and other electronic applications that are consistently used include Twitter, Facebook, Snapchat, emails, SMS, $\&$ MMS. Furthermore, the diverse means of communication represented by some functions within the commercial applications including the following: electronic chat facility with customers, e-mails to receive suggestions to improve the application system, and information about the customers' opinions regarding company-provided services and products. In addition, it might be important to provide quick help channels, such as hot and free lines, to communicate and quickly solve urgent problems for customers. Thus, activating these functions would be beneficial for communicating with customers, which represents one of the key aspects for success and activation of the commercial applications in smartphones.

(iii) Audience foreknowledge: This is defined as previous knowledge of online purchasing methods and the ability to present products across commercial applications that can fill availability gaps by means of explaining as-yet unknown perspectives through currently available data ([66],[68]). Fifty-five percent of female participants expressed the opinion that previous knowledge is important for assisting and teaching customers who have difficulty in making online purchases via commercial applications. This matter is addressed in many functions 
of this study, including the product display, which functions as a changing, rearranging, and sorting feature for the product results in the application. Additional examples include the view function that presents the results horizontally or vertically for easy comparison between the products, and the function that filters the results according to specific criteria and services offered. Furthermore, there are other functions that deal with interesting products for particular consumers, including functions that make product recommendations to customers through email and social media, and functions that provide advice to the customers and offer deals and discounts for online purchasing in a specified time period. Other important functions focus on identifying priorities and displaying products that fit the target audience.

(iv) Audience placement: This involves the audience position through the presentation and description of product features that can both help to make products relevant to customers and display goods to their advantage [67]. For example, if furniture is being featured for online sales, the features of the furniture should be explained to consumers in such a way that they feel as if it was designed specifically for them. These points help consumers internalise the perceived importance of the product. Consequently, these functions assist in the display of the products and present the products' features, helping consumers make the right decisions and enabling them to make electronic purchases as confidently as they would purchase through conventional means. These functions concentrate on multimedia files presenting functions such as text, video, image, or voice files, and these files are professionally designed to be downloaded and displayed at the appropriate time. Furthermore, it might be beneficial to put more than one multimedia option on each screen, allowing product information to be viewed in more detail, since large segments of the GCC follow multimedia files rather than text files. Using the multimedia files would help significantly with attracting an audience; as well as that, they provide alternative formats such as PDF, video, and audio to be used as substitutes in case of unexpected errors in the application, or difficulties in downloading large files. The information that these functions provide to the target audience could be the key factor in the latter's acceptance of online consumer purchasing, since such information makes the product features more readily accessible and the application easier to use.

(v) Audience research: the marketing need research focuses on the importance of the research approach to seeking the target audience in GCC societies for recognise products that can be bought online ([67],[68]). The was study which concentrated on the main groups of products that are appropriate for online purchases. The study noted that the electronic devices, automobiles, clothes, beauty and health, furniture, and jewellery [69]. Purchasing online raises many concerns for people who have no experience using commercial websites or applications related to Arabic companies. Therefore, it is important for companies planning to establish their own electronic trading channels to focus on and know what products interest their target audience, and whether their audience prefers to purchase them online or through traditional sales methods. This will help increase the consumers' level of knowledge regarding electronic purchasing, which will then lead them to make future purchases through electronic channels. The five dimensions and related functions of choosing the target audience represent important criteria to help determine how to attract users to M-commerce applications. They also allow examination of statistical relationships in the ISS model and of the importance of linked moderators, which will be helpful to those engaged in M-commerce.

The five dimensions and related functions of choosing the target audience represent important criteria to help determine how to attract users to M-commerce applications. They will also allow examination of statistical relationships in the ISS model and of the importance of linked moderators, which will be helpful to those engaged in M-commerce.

\subsection{Characteristics of each group}

Four demographic moderators were used in this study. This section focuses on the impact of these moderators on the target population's willingness to accept smartphone commercial applications. These moderators will be helpful in the determination of the main parameters of the target segment characteristics [2]. The moderators also facilitate the identification of relationships between the two main groups, the SQ, IQ, and SQU group and the US/IU group. The following parts highlight the impact of the moderators.

\subsubsection{Gender characteristics}

The differences between the two genders manifested in the differences in opinion that surfaced in this study (similar to some previous studies which mentioned that the women are more likely to shop online than men and they are likely to be bargain hunters more than men) ([59],[70],[71]), led to confirmation in this study that the correlation coefficient for groupings of women demonstrated a greater interest in shopping among that part of the study population, than among men, while no statistically significant differences were present among the groups in the male sample. The female groups in this study were the ones primarily interested in shopping online. The many reasons for this interest can be summarised in four thoughts. First, women may be more likely than men to shop by going through any products to choose one product that is the best [72]; therefore, she needs to look through a variety of options, and online shopping is one of good ways to procure this variety. Secondly, many products provided in online shopping sites means giving women freedom of choice with the comfort of apparent privacy (malicious intrusions, such as website hacking, aside). Thirdly, insufficient numbers of cities in this study have large commercial centres, which may by themselves have provided a variety of options. Finally, there are some strict roles for women that add to the level of inconvenience of their going to physical malls and finding what they want by themselves. These roles are related to Islamic culture, for example, women are not allowed to drive cars, or must be accompanied by a male from the family in public [73]. The lack of shops in small cities and towns in the study compared commercial and mega cities in GCC overall indicates that the stores that are available in many town and small cities don't provide all of the goods (in quantities of desired varieties) for a wide segment of population ([74],[75],[76]). For example, three major commercial cities exist in KSA: Riyadh, Jeddah, and Dammam; one in Qatar, Doha city; and two in the UAE, Dubai and Abu Dhabi. These represent commercial and mega cities receive travelers from other distant cities and small towns when people wish to purchase large or specific products that are not found in their places or the variety products in the larger cities. Therefore, the women are looking to use online 
shopping for the variety of options available in online shopping websites and applications because these products are often not available in traditional markets [76]. The purchasing process from traditional markets also includes many obstacles, including the distance between the commercial and small cities, the high prices of purchase, and the lack of transportation. Because most women in GCC have communities with similar local traditions, they see the importance of taking advantage of online purchasing to provide for their needs and preferences smoothly and easily ([73],[74]). Accordingly, focusing on the female segment in online purchasing might help online shopping succeed overall, and also help the companies' focus on one of the main and right target segments.

\begin{tabular}{|c|c|c|c|c|c|c|c|c|}
\hline \multirow{2}{*}{ KSA } & \multicolumn{2}{|c|}{ Gender } & \multicolumn{2}{|c|}{ Age } & \multicolumn{2}{|c|}{ Frequency } & \multicolumn{2}{|c|}{ Education } \\
\hline & Male & Female & Young & Old & High & Low & PG & UG \\
\hline SQ $\rightarrow$ IU & $0.081^{\mathrm{ns}}$ & $0.314 * * *$ & $0.356 * * *$ & $-0.004^{\mathrm{ns}}$ & $0.463 * * *$ & $0.142^{\mathrm{ns}}$ & $0.402 * * *$ & $0.041^{\text {ns }}$ \\
\hline $\mathrm{SQ} \rightarrow \mathrm{US}$ & $0.412 * * *$ & $0.264 * * *$ & $0.261 * * *$ & $0.380 * *$ & $0.205^{* * *}$ & $0.169 * *$ & $0.200 * * *$ & $0.421 * *$ \\
\hline $\mathrm{IQ} \rightarrow \mathrm{IU}$ & $0.140^{\text {ns }}$ & $0.327 * * *$ & $0.336 * * *$ & $0.022^{\text {ns }}$ & $0.245 * * *$ & $0.172^{\text {ns }}$ & $0.233 * * *$ & $0.100^{\mathrm{ns}}$ \\
\hline IQ $\rightarrow$ US & $0.392 * * *$ & $0.357 * * *$ & $0.416 * * *$ & $0.335 * * *$ & $0.344 * * *$ & $0.409 * * *$ & $0.346 * * *$ & $0.414 * *$ \\
\hline SQU $\rightarrow$ IU & $0.330 * * *$ & $0.552 * * *$ & $0.509 * * *$ & $-0.025^{n s}$ & $0.361 * * *$ & $0.103^{\mathrm{ns}}$ & $0.627 * * *$ & $0.142^{\text {ns }}$ \\
\hline $\begin{array}{c}\text { SQU } \rightarrow \\
\text { US }\end{array}$ & $0.056^{\text {ns }}$ & $0.215 * * *$ & $0.259 * * *$ & $-0.016^{\mathrm{ns}}$ & $0.200 * * *$ & $0.010^{\text {ns }}$ & $0.617 * * *$ & $0.149^{\mathrm{ns}}$ \\
\hline
\end{tabular}

\begin{tabular}{|c|c|c|c|c|c|c|c|c|}
\hline \multirow{2}{*}{ Qatar } & \multicolumn{2}{|c|}{ Gender } & \multicolumn{2}{c|}{ Age } & \multicolumn{2}{c|}{ Frequency } & \multicolumn{2}{c|}{ Education } \\
\cline { 2 - 9 } & Male & Female & Young & Old & High & Low & PG & UG \\
\hline SQ $\rightarrow$ IU & $0.189^{\text {ns }}$ & $0.232^{* * *}$ & $0.281^{* *}$ & $-0.039^{\text {ns }}$ & $0.355^{* * *}$ & $0.229^{\text {ns }}$ & $-0.154^{\text {ns }}$ & $0.155^{\text {ns }}$ \\
\hline SQ $\rightarrow$ US & $0.262^{* * *}$ & $0.329^{* * *}$ & $0.323^{* * *}$ & $0.241^{* * *}$ & $0.334^{* * *}$ & $0.327^{* * *}$ & $0.422^{* * *}$ & $0.388^{* * *}$ \\
\hline IQ $\rightarrow$ IU & $0.017^{\text {ns }}$ & $0.281^{* * *}$ & $0.376^{* *}$ & $0.008^{\text {ns }}$ & $0.249^{* *}$ & $-0.061^{\text {ns }}$ & $-0.225^{\text {ns }}$ & $0.262^{\text {ns }}$ \\
\hline IQ $\rightarrow$ US & $0.470^{* * *}$ & $0.374^{* * *}$ & $0.505^{* * *}$ & $0.371^{* * *}$ & $0.484^{* * *}$ & $0.510^{* * *}$ & $0.293^{* *}$ & $0.407^{* * *}$ \\
\hline SQU $\rightarrow$ IU & $-0.060^{\text {ns }}$ & $0.378^{* * *}$ & $0.416^{* * *}$ & $-0.153^{\text {ns }}$ & $0.260^{* * *}$ & $-0.202^{\text {ns }}$ & $-0.150^{\text {ns }}$ & $0.280^{\text {ns }}$ \\
\hline $\begin{array}{c}\text { SQU } \rightarrow \\
\text { US }\end{array}$ & $0.015^{\text {ns }}$ & $0.376^{* * *}$ & $0.465^{* * *}$ & $-0.043^{\text {ns }}$ & $0.313^{* *}$ & $-0.114^{\text {ns }}$ & $0.261^{\text {ns }}$ & $-0.100^{\text {ns }}$ \\
\hline
\end{tabular}

\begin{tabular}{|c|c|c|c|c|c|c|c|c|}
\hline \multirow{2}{*}{ UAE } & \multicolumn{2}{|c|}{ Gender } & \multicolumn{2}{|c|}{ Age } & \multicolumn{2}{|c|}{ Frequency } & \multicolumn{2}{|c|}{ Education } \\
\hline & Male & Female & Young & Old & High & Low & PG & UG \\
\hline$S Q \rightarrow$ IU & -0.047 & $0.309 * * *$ & $0.289 * * *$ & $0.051^{\text {ns }}$ & $0.039^{\text {ns }}$ & $0.265^{\mathrm{ns}}$ & $0.108^{\text {ns }}$ & $0.049^{\text {ns }}$ \\
\hline$S Q \rightarrow$ US & $0.264 * * *$ & $0.564 * * *$ & $0.407 * * *$ & $0.483 * * *$ & $0.502 * * *$ & $0.304^{* * *}$ & $0.450 * * *$ & $0.424^{* * *}$ \\
\hline IQ $\rightarrow$ IU & $0.173^{\mathrm{ns}}$ & $0.376 * * *$ & $0.342 * * *$ & $0.152^{\mathrm{ns}}$ & $-0.028^{\mathrm{ns}}$ & $0.380 * * *$ & $0.199^{\mathrm{ns}}$ & $0.049^{\mathrm{ns}}$ \\
\hline IQ $\rightarrow$ US & $0.635 * * *$ & $0.653 * * *$ & $0.634 * * *$ & $0.672 * * *$ & $0.686 * * *$ & $0.536 * * *$ & $0.626 * * *$ & $0.424 * * *$ \\
\hline SQU $\rightarrow$ IU & $0.022^{\text {ns }}$ & $0.384 * * *$ & $0.384 * * *$ & $-0.085^{n s}$ & $0.048^{\text {ns }}$ & $-0.246^{\mathrm{ns}}$ & $-0.126^{\mathrm{ns}}$ & $0.049^{\mathrm{ns}}$ \\
\hline $\begin{array}{c}\text { SQU } \rightarrow \\
\text { US }\end{array}$ & $0.034 * * *$ & $0.357 * * *$ & $0.300 * * *$ & $0.03^{\mathrm{ns}}$ & $0.140^{\mathrm{ns}}$ & $0.204^{\mathrm{ns}}$ & $0.176^{\text {ns }}$ & $0.424^{\mathrm{ns}}$ \\
\hline
\end{tabular}

$S Q=$ System Quality, IQ = Information Quality, SQU = Service Quality, IU = Intention to Use, US = User Satisfaction, - ${ }^{*} p<$ $0.1 ;{ }^{* *} p<0.05 ;{ }^{* * *} p<0.001$. ns $=$ Not significant

\begin{tabular}{c|c|c|c}
$\begin{array}{c}\text { Single Path Group is } \\
\text { significant }\end{array}$ & $\begin{array}{c}\text { Both parts of Moderator } \\
\text { Group are significant }\end{array}$ & $\begin{array}{c}\text { Moderator Group is } \\
\text { Significant }\end{array}$ & $\begin{array}{c}\text { Path significant in all } \\
\text { moderator groups }\end{array}$
\end{tabular}

\subsubsection{Age characteristics}

The age moderator divided the age into a young and old group. There is a line between young adulthood, which includes those searching for a permanent job and those creating a new family and stability, and reaching to these requirements in GCC because the adulthood represent $62.5 \%$ in GCC societies ([61],[62],[63],[81]). In all of the sample group countries, the results appear to show that young people are more likely to accept changes in technology. Many previous studies show the importance of the young age group because they accept change more readily than their elders; the young age group is keen to deal with innovative technology and adapts to the requirements and advances of the current era ([75],[77],[78]). The young age group in our study was keen to use technology and accept it; they have the ability to engage in and are interested in online shopping, and these manifested as significant differences with the older participants in this study ([78],[79]). Furthermore, the key questions (Conditional Questions) asked in the beginning of the questionnaire reveal that $61 \%$ of the responding population was less than 35 years old. Overall, the young are a promising segment of society with respect to the acceptance and diffusion of an online-shopping traditions. Technical applications allow young people to open their own businesses and use new experiences that were unknown to the previous generations in their countries. These applications will be beneficial for independent growth in this segment; they will have less need of government jobs and new shopping fields should appear due to the increased income attendant on technology jobs [80]. Most of the studies that address Mcommerce projects in the Middle East are devised and executed by young people using small capital budgets in a way that is not comparable with the empire of traditional trade from the past. Nonetheless, these projects are lucrative compared to traditional trading, leading major companies in GCC region to present their products for sale online [81]. 


\subsubsection{Frequency characteristics}

In the frequency group, previous studies and the results of this study confirm the importance of previous experience to a specific community's acceptance of electronic systems. Those who have previously and frequently used a system are helpful in breaking down the fear that exists for many who start to use new electronic systems. The study shows that people who purchase online more than once a month are helpful in changing participants' convictions related to the importance of M-commerce through smartphones [77]. The effect of highpurchase segments (that is, more than once a month) provides the vital experience necessary to promote the use of commercial applications. The moderator shows a significant relationship with the high-frequency slices of online purchasing in KSA and Qatar. Conversely, the moderator does not appear to be significant in the UAE. This means that the frequency moderator has a different effect in countries that did not adopt an M-commerce approach widely, as the online purchasing acceptance stage did not move on to the following stages of adoption, diffusion, and success. In the UAE segment, the participant results indicate that the UAE developed a larger e-commerce infrastructure than other GCC countries because of the openness of its global trading ([82],[83]). The free trade area in the UAE reflects positively on the community characteristics, and the moderator no longer must have a given effect in order to spread the acceptance of electronic systems among the people in the UAE. Rather, in the UAE, obstacles have been removed to facilitate widespread acceptance of M-commerce [84]. The infrastructure of M-commerce and services in the UAE has been designed to help the inexperienced purchase goods and services online, these communities have a slightly different level of acceptance of electronic systems from other communities

\subsubsection{Education level characteristics}

Some previous research indicates that the importance of education level and the correlation between levels of education and acceptance of e-commerce and vice versa is considerable due to their strong relations [74]. The main concern in this study is the importance of education in increasing consumer awareness of online purchasing and the benefits of such purchasing to a wide sector ([73],[85],[86]). The results of this study indicate the importance of educational level to spreading awareness of online purchasing through smartphone application in the GCC societies. In this study, the education level moderator was of more significance in the KSA for higher education group than in the others, but there was no significance in having a bachelor degree in the KSA group or in the groups from Qatar and the UAE. Additionally, the higher education segment in KSA was a reliable leader with respect to solving serious issues surfacing around ways to provide electronic systems that facilitate Mcommerce in a more widespread fashion [95]. Therefore, education level is one of the main determinants of the target population and can be used to increase levels of confidence with respect to technology acceptance in KSA; these findings are different from those in Qatar and UAE. KSA overall also has a larger proportion of people with an advanced degree than does Qatar or UAE. This impact on the influence of all three countries on their nearest neighbours in the GCC as well as on the percentage of people within the three countries who are aware of the importance of electronic systems and Mcommerce, which may lead to increasing awareness in various societies around the GCC.

\subsection{The characteristics of special paths of relationship and their significance}

The previous section presented the demographic moderators used in this study and their impact on ISS in the commercial applications of smartphones. Certain paths of relationship have yielded significant results in each moderator group; it might be important to study the impact of these paths on the success of commercial applications in the target audience.

As mentioned in the data analysis chapter, moderators exert their impact through the relationships between customer requirements (SQ, IQ, and SQU) and between customer behaviour (US and IU). The number of these relationships is six (see Table 3). Two of these paths are statistically significant across the entire group of moderators and the study samples. These paths are the SQ $\rightarrow$ US and IQ $\rightarrow$ US. The results indicate the importance of SQ and IQ on US in smartphone commercial applications similar to the DeLone and McLean's-1992 and Seddon models ([11],[18]). As mentioned previously, the importance of User Satisfaction depends on the quality of systems, information, and service. IQ and SQ have been shown to be significant across all groups of moderators; however SQU was significant in many of the moderator group (See Table 3). The study samples provide an explanation for this: there are two levels of requirements with the use of commercial applications. The first level is the requirements for which the smartphone applications cannot work without their being correct; this leads to the importance of US in smartphone commercial applications. SQ and IQ functions are two of these requirements, similar to the Seddon model [11]. The second level is the SQU requirements, which focus their functions on the availability of communication channels, the capability to search and ask about difficult aspects of use, and the building of loyalty by giving rewards programs, which occupies second level of importance based on the results of for participants when using the moderators ([7],[15]). Therefore, the results of the SQU path are not statistically significant in all groups (See Table 3). The results that did show significance were for the construct of SQU (with $45.8 \%$ considering it of importance), while the rest of the results were not statistically significant.

Besides that, significant relationships do not appear in paths associated with the IU as they are full significant paths in US. The significant relationships and their ratings among the entire group of moderators are as follows: $54.2 \%$ of moderators' groups in KSA, $37.5 \%$ of groups in Qatar, and $29.2 \%$ of groups in UAE have significant relationships in the moderators' groups. The results show that the IU has some large challenges to surmount among M-commerce companies and the e-commerce sector in the GCC. Competition from large companies to attract and build loyalty among target audiences is open for people who would like to 'try out' this experience through interested online shopping companies.

Relationships that focus on the differences between two groups for each moderator or path in the study samples clearly show the importance of benefiting from these moderator groups to determine the parameters and main characteristics of the target audience. Additionally, significant relationships give indications of the importance of an entity; the most important entity would be one that shows significant relationships across all statistical paths, which helps to build a more efficient model. Moreover, relationships that do not show significant results or results that support the basic research objectives should be ignored. The features and characteristics of the target audience are emphasised through the target audience characteristics model in the next section. 
This section has focused on the correlation results among the constructs, concentrating on the impact of demographic moderators on customer requirements and behaviour and culminating in an evaluation of the requirements for success in the ISS model. Key aspects and parameters of identifying the target audience characteristics for successful identification of an M-commerce target audience were discussed (see Table 3). The results also revealed some individual, statistically significant relationships that do not have any specific role; these were described in some detail. Lastly, the relationship of both US and IU to NB is described for the use of Mcommerce applications, focusing on the relationship of these constructs with M-commerce acceptance.

\section{IMPLICATION}

Customer retention and relationship management are a company's responsibility regarding the increase of customer satisfaction and loyalty ([42],[87]). As mentioned previously, creating customer loyalty is a key source of competition between companies; therefore, it is important to activate electronic systems to retain customer segments and their loyalty $([43],[46])$. One main objective in this study is to provide the requirements that might be helpful in building customer satisfaction such as providing products that are interesting to each customer and information on the release of new products. This method is believed to be much more helpful for retaining customers ([20],[40]). Providing the appropriate response at the appropriate time in the appropriate manner to customers, not to the company, without any annoyance to customers, would help solidify customer satisfaction and retention ([13],[44]). Therefore, it is important for the Chief Information Officers (CIOs) of online shopping companies to increase communication levels, provide diverse communication features appropriate for customers, and develop tools that significantly increase the levels of intent to re-use and customer loyalty ([43],[69],[88]).

Gradual customer loyalty improves the net benefits perceived through M-commerce systems ([25],[27],[46],[87],[89]). This is expected to increase US and the IU, which will gain customer loyalty for the future. Furthermore, it is important for commercial companies to invest in electronic methods to attract customers through a variety of technological means that concentrate on consumer behaviour for online purchasing via electronic systems such as decision-making techniques for online purchasing ([87],[90]). This can be accomplished through the provision of adequate and sufficient characteristics of products and appropriate multimedia files that are helpful for making the right decision at the right time ([88],[91]). To increase the level of IU, M-commerce system developers must establish those customer requirements that contain adequate information of systems and application quality together ([92],[93]). This information can positively impact the required net benefit, which leads to an increase in the level of US and hopefully influences the IU mobile commercial systems in the future.

The NB might focus on a strategic objective in M-commerce to measure the successful level in technical support management departments that are concerned with online trading in companies [2]. This represents a primary motivation for companies' managers to continue to support and activate electronic systems and to ensure that success spreads among customers while focusing on increasing loyalty programs to expand the size of the target population ([43],[46],[88]). Additionally, NB mostly result from US through the implementation of M-commerce strategies ([25],[94]). It is important for companies to track policy changes that appear in
US requirements, which are diverse because US comes at the intermediate level between NB and IU on one side and Customer Requirement Qualities on the other.

\section{CONCLUSION}

This paper focusses on the essential characteristics of the target audience for smartphone commercial applications. Thus, the study sought to determine the segment characteristics that will be helpful to spread the awareness of using commercial applications in GCC societies. Therefore, future studies will concentrate on two main issues, which are determining the technical requirements represented by technical functions and identifying the differences in these requirements from one community to another.

The commercial applications will help to target a large segment of users who are interested to take advantage of commercial applications through many benefits in the $\mathrm{m}$ commerce field. Therefore, spreading the commercial applications will depend on contacting people who interested in using these applications instead of gaining the loyalty of new customers, which is more expensive than maintaining relationships with old customers who are already interested in making online purchases. Subsequently, making an effort to retain the target audience will facilitate the diffusion of commercial applications, thereby reaching a larger population in the future.

\section{REFERENCES}

[1] Khan, H., Talib, F., \& Faisal, M. N. (2015). An analysis of the barriers to the proliferation of M-commerce in Qatar: A relationship modeling approach. Journal of Systems and Information Technology, 17(1), 54-81.

[2] Wang, Y. S. (2008). Assessing e-commerce systems success: a respecification and validation of the DeLone and McLean model of IS success. Information Systems Journal, 18(5), 529-557.

[3] Chang, Y. S. (2015). Cultural differences in the context of fast food website design: a comparison of Taiwan and the United States.

[4] Qingfei, M., Shaobo, J., \& Gang, Q. (2008). Mobile commerce user acceptance study in China: a revised UTAUT model. Tsinghua Science \& Technology, 13(3), 257-264.

[5] Wamda, (2013). PayPal's report on e-commerce and new trends Retrieved October 6, 2015, from http://nabdapp.com/jump_ios.php?id=5660000

[6] Petter, S., DeLone, W., \& McLean, E. (2008). Measuring information systems success: models, dimensions, measures, and interrelationships. European Journal of Information Systems, 17(3), 236-263.

[7] Delone, W. H., \& Mclean, E. R. (2004). Measuring ecommerce success: applying the DeLone \& McLean information systems success model. International Journal of Electronic Commerce, 9(1), 31-47.

[8] Wang, Y. S., Lin, H. H., \& Luarn, P. (2006). Predicting consumer intention to use mobile service. Information systems journal, 16(2), 157-179.

[9] Molla, A., \& Licker, P. S. (2001). E-Commerce Systems Success: An Attempt to Extend and Respecify the Delone and McLean Model of IS Success. J. Electron. Commerce Res., 2(4), 131-141. 
[10] Seddon, P., \& Kiew, M.-Y. (2007). A partial test and development of DeLone and McLean's model of IS success. Australasian Journal of Information Systems, 4(1).

[11] Seddon, P. B. (1997). A respecification and extension of the DeLone and McLean model of IS success. Information systems research, 8(3), 240-253.

[12] Liu, C., \& Arnett, K. P. (2000). Exploring the factors associated with Web site success in the context of electronic commerce. Information \& management, 38(1), 23-33.

[13] Wang, E. H. H., \& Chao-Yu, C. (2011). System Quality, User Satisfaction, and Perceived Net Benefits of Mobile Broadband Services.

[14] Rai, A., Lang, S. S., \& Welker, R. B. (2002). Assessing the validity of IS success models: An empirical test and theoretical analysis. Information systems research, 13(1), $50-69$.

[15] Delone, W. H., \& McLean, E. R. (2003). The DeLone and McLean model of information systems success: a ten-year update. Journal of management information systems, 19(4), 9-30.

[16] Zeithaml, V. A. (1988). Consumer perceptions of price, quality, and value: a means-end model and synthesis of evidence. The Journal of marketing, 2-22.

[17] Bernroider, E. W. (2008). IT governance for enterprise resource planning supported by the DeLone-McLean model of information systems success. Information \& Management, 45(5), 257-269.

[18] DeLone, W. H., \& McLean, E. R. (1992). Information systems success: the quest for the dependent variable. Information Systems Research, 3(1), 60-95.

[19] Wang, Y.-S., \& Liao, Y.-W. (2007). The conceptualization and measurement of m-commerce user satisfaction. Computers in Human Behavior, 23(1), 381398.

[20] Ho, R., Huang, L., Huang, S., Lee, T., Rosten, A., \& Tang, C. S. (2009). An approach to develop effective customer loyalty programs: The VIP program at T\&T Supermarkets Inc. Managing Service Quality: An International Journal,19(6), 702-720.

[21] Marti, N. \& Charles, V. (2013). M-commerce: Mcommerce: a consumer perspective. (Student paper). Högskolan i Halmstad

[22] Petter, S., DeLone, W., \& McLean, E. R. (2013). Information Systems Success: the quest for the independent variables. Journal of Management Information Systems, 29(4), 7-62.

[23] Gable, G. G., Sedera, D., \& Chan, T. (2008). Reconceptualizing information system success: The ISimpact measurement model. Journal of the association for information systems, 9(7), 18 .

[24] IVES, B., Olson, M. H., \& Baroudi, J. J. (1983). The measurement of user information satisfaction. Communications of the ACM, 26(10), 785-793.

[25] Legner, C. (2011). Evaluating Mobile Business Applications in Service and maintenance Processes: Results of A Quantitative-empirical study.
[26] Monroe, K. B. (1990). Price: Making profitable decisions. New YorkMcGraw-Hill.

[27] Parasuraman, A., \& Grewal, D. (2000). The impact of technology on the quality-value-loyalty chain: a research agenda. Journal of the academy of marketing science, 28(1), 168-174.

[28] Pitt, L. F., Watson, R. T., \& Kavan, C. B. (1995). Service quality: a measure of information systems effectiveness. MIS quarterly, 173-187.

[29] Varnali, K., \& Toker, A. (2010). Mobile marketing research: The-state-of-the-art. International Journal of Information Management, 30(2), 144-151.

[30] Wang, Y. S., \& Tang, T. I. (2003). Assessing customer perceptions of website service quality in digital marketing environments. Journal of Organizational and End User Computing (JOEUC), 15(3), 14-31.

[31] Lu, M. T., Hu, S. K., Huang, L. H., \& Tzeng, G. H. (2015). Evaluating the implementation of business-tobusiness m-commerce by SMEs based on a new hybrid MADM model. Management Decision, 53(2), 290-317.

[32] Parasuraman, A., Zeithaml, V. A., \& Malhotra, A. (2005). ES-QUAL a multiple-item scale for assessing electronic service quality. Journal of service research, 7(3), 213-233.

[33] Lee, K. C., \& Chung, N. (2009). Understanding factors affecting trust in and satisfaction with mobile banking in Korea: A modified DeLone and McLean's model perspective. Interacting with computers, 21(5), 385-392.

[34] Joubert, J., \& Belle, J. P. V. (2009). The importance of trust and risk in M-commerce: A South African perspective. PACIS 2009 Proceedings, 96.

[35] Aladwani, A. M. (2002). Organizational actions, computer attitudes, and end-user satisfaction in public organizations: An empirical study. Journal of Organizational and End User Computing, 14(1), 42.

[36] Al-adaileh, R. (2009). An evaluation of information systems success: A user perspective-the case of Jordan Telecom Group. European Journal of Scientific Research, 37(2), 226-239.

[37] Davis, F. D. (1989). Perceived usefulness, perceived ease of use, and user acceptance of information technology. MIS quarterly, 319-340.

[38] Eid, M. I. (2011). Determinants of e-commerce customer satisfaction, trust, and loyalty in Saudi Arabia. Journal of Electronic Commerce Research, 12(1), 78-93.

[39] Caruana, A., \& Fenech, N. (2005). The effect of perceived value and overall satisfaction on loyalty: A study among dental patients. Journal of Medical Marketing: Device, Diagnostic and Pharmaceutical Marketing, 5(3), 245-255.

[40] Hossain, M. Y., \& Hossain, M. (2011). E-Service Quality and Consumer Loyalty: A study on Consumer Electronic Retail Industry.

[41] Hair, J. F., Black, W., Babin, B., \& Anderson, R. (2010). Multivariate data analysis: a global perspective (7th ed.). New Jersey: Pearson.

[42] Wahab, S., Zahari, A. S. M., Al Momani, K., \& Nor, N. A. M. (2011). The influence of perceived privacy on 
customer loyalty in mobile phone services: An Empirical Research in Jordan. IJCSI, 45.

[43] Ahmed, N., Majid, M., Nadeem, M., \& Jalbani, S. M. (2013). The impact of service quality on brand loyalty; mediating role of customer satisfaction. European Journal of Management Sciences, 1(1), 30-41.

[44] Amin, M., Rezaei, S., \& Abolghasemi, M. (2014). User satisfaction with mobile websites: the impact of perceived usefulness (PU), perceived ease of use (PEOU) and trust. Nankai Business Review International, 5(3), 258-274.

[45] Bai, B., Law, R., \& Wen, I. (2008). The impact of website quality on customer satisfaction and purchase intentions: Evidence from Chinese online visitors. International Journal of Hospitality Management, 27(3), 391-402.

[46] Lin, H. H., \& Wang, Y. S. (2006). An examination of the determinants of customer loyalty in mobile commerce contexts. Information \& management, 43(3), 271-282.

[47] Yang, Z., Jun, M., \& Peterson, R. T. (2004). Measuring customer perceived online service quality: scale development and managerial implications. International Journal of Operations \& Production Management, 24(11), 1149-1174.

[48] Lam, S. Y., Shankar, V., Erramilli, M. K., \& Murthy, B. (2004). Customer value, satisfaction, loyalty, and switching costs: an illustration from a business-tobusiness service context. Journal of the academy of marketing science, 32(3), 293-311.

[49] Dai, H., \& Palvi, P. C. (2009). Mobile commerce adoption in China and the United States: a cross-cultural study. ACM SIGMIS Database, 40(4), 43-61.

[50] Bagozzi, R. P. (1992). The self-regulation of attitudes, intentions, and behavior.Social psychology quarterly, 178-204.

[51] Chang, S. C., Sun, C. C., Pan, L. Y., \& Wang, M. Y. (2015). An Extended TAM to Explore Behavioural Intention of Consumers to Use M-Commerce. Journal of Information \& Knowledge Management, 1550014.

[52] Lee, H. M., \& Chen, T. (2014). Perceived Quality as a Key Antecedent in Continuance Intention on Mobile Commerce. International Journal of Electronic Commerce Studies, 5(2), 123-142.

[53] Chen, C. W. D., \& Cheng, C. Y. J. (2009). Understanding consumer intention in online shopping: a respecification and validation of the DeLone and McLean model. Behaviour \& Information Technology,28(4), 335-345.

[54] Creswell, J. W. (2008). Educational Research: Planning, Conducting, and Evaluating Quantitative and Qualitative Research: Pearson/Merrill Prentice Hall.

[55] Sekaran, U. (2003). Research methods for business: a skill building approach. Journal of Education for Business, 68(5), 316-317.

[56] Wuensch, K. (2005). What is a Likert Scale? and How Do You Pronounce 'Likert?. East Carolina University. Retrieved 22 November 2015 from http://core.ecu.edu/psyc/ wuenschk/StatHelp/Likert.htm.
[57] Kline, R. B. (2005). Principles and Practice of Structural Equation Modeling (2nd edn ed.). New York: Guilford Press.

[58] Pallant, J. (2005). SPSS Survival Manual: A Step by Step Guide to Data Analysis using SPSS for Windows (Version 12). Berkshire: Open University Press.

[59] Deng, Z., Lu, Y., Wei, K. K., \& Zhang, J. (2010). Understanding customer satisfaction and loyalty: An empirical study of mobile instant messages in China. International Journal of Information Management, 30(4), 289-300.

[60] Venkatesh, V., Ramesh, V., \& Massey, A. P. (2003). Understanding usability in mobile commerce. Communications of the ACM, 46(12), 53-56.

[61] CDSI (2016), Statistical Summary of Teaching Adm. \& Tec. Staff By Agency-2010, Retrieved May 11, 2016 from

https://docs.google.com/viewerng/viewer?url=http://ww w.stats.gov.sa/sites/default/files/ar-edu0000-012014 0.xls

[62] QSAb (2015), CHAPTER IV EDUCATION STATISTICS, Retrieved March 20, 2016 from http://www.gsdp.gov.qa/ portal/page/portal/ GSDP_AR/knowledge_center_ar/Tab2/4_Education_201 4_edu.pdf

[63] UAE STATISTICS (2016). Federal Competitiveness and Statistics Authority, Retrieved March 15, 2016 from http://www.fcsa.gov.ae/Home/ReportDetails1/tabid/90/D efault.aspx?ItemId=2399\&PTID=129\&MenuId=1

[64] Harris, P., Rettie, R., \& Cheung, C. K. (2005). Adoption and usage of m-commerce: a cross-cultural comparison of Hong Kong and the United Kingdom. Journal of Electronic Commerce Research, 6(3), 210-224.

[65] Zakour, A. B. (2004). Cultural differences and information technology acceptance. Paper presented at the Proceedings of the 7th Annual Conference of the Southern Association for Information Systems.

[66] Holzwarth, E. (August 15, 2015). Smartphone Market Demographics. Retrieved September 17, 2015 from http://littlegreensoftware.com/blog/strategy/smartphonemarket-demographics

[67] PITT (n.d.). Audience Adaptation Retrieved from University of Pittsburgh September 25, 2015 from http://www.speaking.pitt.edu/stud ent/publicspeaking/audienceadaptation.html

[68] Dodkins, C. (Mar 24, 2010). Understanding audiences and target audiences. Retrieved September 17, 2015 from http://www.slideshare.net/guest14c40ed3/understandingaudiences-and-target-audiences-35377 92?related=1

[69] Bahaddad, A. A., AlGhamdi, R., \& Alkhalaf, S. (2014). Adoption Factors for e-Malls in the SME Sector in Saudi Arabia. arXiv preprint arXiv:1504.01112.

[70] Li, S., Glass, R., \& Records, H. (2008). The influence of gender on new technology adoption and use-mobile commerce. Journal of Internet Commerce, 7(2), 270-289.

[71] Payment Sense. (2015). INFOGRAPHIC of Do men and women shop differently online. Retrieved September 7, 2015 from http://www.paymentsense.co.uk/men-vswomen-online/ 
[72] Coverdale, T. S., \& Morgan, A. J. (2013). The influence of identity characteristics on E-Shopping enjoyment and E-Loyalty among women online shoppers. Journal of Technology Research, 4, 1.

[73] Bahaddad, A. A., Drew, S., Houghtoni, L., \& Alfarraj, O. A. (2015). Factors attracting online consumers to choose e-Malls for e-procurement in Saudi Arabia. Enterprise Information Systems, 1-32.

[74] AlGhamdi, R., Alfarraj, O. A., \& Bahaddad, A. A. (2015). How Retailers at different Stages of E-Commerce Maturity Evaluate Their Entry to E-Commerce Activities?. arXiv preprint arXiv:1503.05172.

[75] Khalil, N. (2014). Factors affecting the consumer's attitudes on online shopping in Saudi Arabia. International Journal of Scientific and Research Publications, Volume 11(4), 8

[76] Zorzini C. (June 15 2015). Infographic: Online Shopping Habits Men vs. Women. Retrieved November 19, 2015 from http://ecommerce-platforms.com/ecommercenews/infographic-online-shopping-habits-men-vs-women

[77] Marketing Charts Staff, (March 2, 2009). Old and Young Use Internet Differently, Retrieved August 25, 2015 from http://www.marketingcharts.com/ online/generationsonline-use-internet-differently-8145/

[78] Rigby, C. (January 30, 2012). Older shoppers power online spending Retrieved September 24, 2015 from http://internetretailing.net/2012/01/older-shopperspower-online-spending-research/

[79] Aitnews. (2013, August 27). UAE and Saudi Arabia of the most commonly used of smartphones in the world. Arab Portal Technical News. Retrieved October 20, 2015, http://www.aitnews.com/latest-it-news/technologyresearch-and-studies-news/119939.html

[80] Dokkanafkar. (2015). 'Shop of Ideas:' the Promise of Online Shopping in Saudi Arabia Retrieved September 17, 2015. from https://www.dokkanafkar. com/\%E2\%80\%98Shop+of+Ideas $\% 3$ A\%E2\%80\%99+th e+Promise+of+Online+Shopping+in+Saudi+Arabia

[81] Bahaddad, A. A., Houghton, L., \& Drew, S. (2013). Attracting Customer in Saudi Arabia to Buy from Your Business Online. International Journal of Business and Management, 8(7), 17.

[82] Emirates 24/7 News, (July 16, 2013). Dubai launches new website, app for daily shopping Retrieved September 17, 2015 from http://www.emirates 247 .com/news/emirates/dubai-launches-new-website-app- for-daily-shopping-2013-07-16-1.514466

[83] Qshop. (2015). Shopping Application give ease to frequent Online Shoppers! Retrieved September 22, 2015 from http://qshopuae.com/blog/

[84] Hanif, N. (August 20, 2013). Consumer protection for UAE's online shoppers. Retrieved September 17, 2015 from http://www.thenational.ae/news/uaenews/consumer-protection-for-uaes-online-shoppers

[85] MacGregor R.C. (2004). Factors associated with formal networking in regional small business: some findings from a study of Swedish SMEs. Journal of Small Business and Enterprise Development, 11(1), 15

[86] Xu J., \& Quaddus M. (2004). Adoption and diffusion of knowledge management systems: An Australian survey. Journal of Management Development, 24(4), 27

[87] Suki, N. M., \& Suki, N. M. (2014). Mobile social networking service users' trust and loyalty. Mobile Electronic Commerce: Foundations, Development, and Applications, 89.

[88] Li, H. \& Suomi, R. (2009). A proposed scale for measuring e-service quality. International Journal of $\mathrm{u}$ and e-Service, Science and Technology,2(1), 1-10

[89] Wu, J. H., \& Wang, Y. M. (2006). Measuring KMS success: A respecification of the DeLone and McLean's model. Information \& Management, 43(6), 728-739.

[90] LaMalfa, K. (2007), The Top 11 Ways to Increase Your Employee Loyalty, Business Week Technology Research, White Paper.

[91] Zahra, S., Khalid, A., \& Javed, A. (2013). An Efficient and Effective New Generation Objective Quality Model for Mobile Applications. International Journal of Modern Education and Computer Science (IJMECS), 5(4), 36.

[92] Chen, L. \& Skelton, G. (2005). Mobile Commerce Application Development: CyberTeeh Publishing, USA.

[93] McWherter, J., \& Gowell, S. (2012). Professional Mobile Application Development: Wiley.

[94] Chiou, W.-C., Lin, C.-C., \& Perng, C. (2010). A strategic framework for website evaluation based on a review of the literature from 1995-2006. Information \& management, 47(5), 282-290.

[95] Taylor, C., \& Albasri, W. (2014). The Impact of Saudi Arabia King Abdullah's Scholarship Program in the US. Open Journal of Social Sciences, 2(10), 109. 